\title{
Molecular Characterization of Some Saprophyte Agrobacterium Strains Isolated from Root Nodules of Cicer arietinum L. Cultivated in Central Anatolia Region of Turkey
}

\author{
Cem Tolga GÜRKANLI \\ Department of Fisheries Technology Engineering, Fatsa Faculty of Marine Sciences, Ordu University, 52400, Fatsa, Ordu/Turkey.
}

How to cite: Gürkanl, C.T. (2020). Molecular Characterization of Some Saprophyte Agrobacterium Strains Isolated from Root Nodules of Cicer arietinum L. Cultivated in Central Anatolia Region of Turkey. J. Anatolian Env. and Anim. Sciences, 5(4), 475-483.

Atıf yapmak için: Gürkanlı, C.T. (2020). Türkiye'nin İç Anadolu Bölgesinde Yetiştirilen Cicer arietinum L.'nin Kök Nodüllerinden İzole Edilmiş Bazı Saprofit Agrobacterium Suşlarının Moleküler Karakterizasyonu. Anadolu Çev. ve Hay. Dergisi, 5(4), 475-483.

https://orcid.org/0000-0001-8378-7109

\begin{abstract}
In the present study, twelve plant-associated bacteria which isolated from root nodules of C. arietinum L. collected from Central-Anatolia region of Turkey were identified with current molecular techniques. None of the isolates produced root nodules or showed pathogenic effects (gall or hairy root) on the original host as the result of authentication and pathogenicity tests, respectively. These results have suggested that all these isolates are root endophytic bacteria. Additionally, PCR amplifications for nodD and virA genes did not reveal any bands. These results showed that these isolates have not to harbour symbiotic (pSym) or pathogenicity (Ti: Tumour inducing or Ri: Root inducing) plasmids which are necessary for nodulation and virulence, respectively. TP-RAPD analysis revealed three patterns indicating three genetically distinct groups within the isolate collection. From each pattern, one representative isolate was selected for further molecular analyses. Phylogenetic analyses depending on nucleotide sequences of 16S rDNA and recA genes assigned representative isolates of Pattern-A ( $n: 4)$ and Pattern-B $(n: 6)$ as A. radiobacter. On the other hand, the representative isolate of Pattern-C $(n: 2)$ appeared as related to A. nepotum. As a result, this study presents the first phylogenetically identified root-endophytic Agrobacterium radiobacter and A. nepotum isolates from root nodules of $C$. arietinum L. grown in Central Anatolia part of Turkey. Additionally, the first molecular data of $A$. radiobacter for Turkey also presented.
\end{abstract}

Keywords: Agrobacterium, Chickpeas, Nodulation, Phylogeny, Virulence.

\section{Türkiye’nin İç Anadolu Bölgesinde Yetiştirilen Cicer arietinum L.’nin Kök Nodüllerinden İzole Edilmiş Bazı Saprofit Agrobacterium Suşlarının Moleküler Karakterizasyonu}

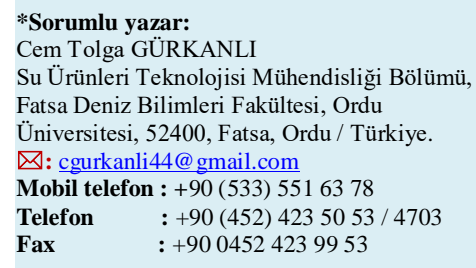

Öz: Bu çalışmada Türkiye'nin İç Anadolu bölgesinden toplanan C. arietinum L. bitkisinin kök nodüllerin'den izole edilmiş on iki bitki ilişkili bakteri moleküler teknikler kullanılarak teșhis edilmiştir. $\mathrm{Bu}$ izolatların hiç birisi otantikasyon ve patojenite testlerinin sonucunda orijinal konak üzerinde nodül oluşturmamış veya patojenik etki (gall oluşumu veya saçak kök oluşumu) göstermemiştir. Bu sonuçlar bütün bu izolatların kök endofitik bakteriler olduğunu ortaya koymuştur. Ek olarak nodD ve virA genleri için yapılan PCR amplifikasyonları herhangi bir bant ortaya koymamıştır. Bu sonuçlar bu izolatların nodülasyon veya virülans için gerekli olan sırasıyla simbiyotik (pSym) veya patojenite (Ti: Tümör oluşturan veya Ri: Saçak kök oluşturan) pilazmitlerini taşımadıklarını göstermiştir. TP-RAPD analizi izolat kolleksiyonu içerisinde genetik olarak ayrı üç gruba işaret eden üç şablon ortaya koymuștur. İleri moleküler analizler için her şablondan bir temsilci izolat seçilmiştir. 16S rDNA ve recA genlerinin nükleotid dizilerine dayalı filogenetik analizler ŞablonA $(n: 4)$ ve Sablon-B'nin ( $n: 6)$ temsilci izolatlarını Agrobacterium radiobacter türü ile ilişkilendirmiştir. Diğer taraftan, Şablon-C'nin (n:2) temsilci izolatı A. nepotum olarak ortaya çıkmıştır. Sonuç olarak bu çalıșma Türkiye'nin İç Anadolu Bölgesinde yetiștirilen $C$. arietinum L.'nin kök nodüllerin'den filogenetik olarak tanımlanmış ilk kök endofitik Agrobacterium radiobacter and A. nepotum izolatlarını sunmaktadır. Ek olarak, A. radiobacter için Türkiye'den ilk moleküler verileri de sunmaktadir.

Anahtar kelimeler: Agrobacterium, Filogeni, Nodülasyon, Nohut, Virülans. 


\section{INTRODUCTION}

The genus Agrobacterium (Class: Alphaproteobacteria, Order: Rhizobiales, Family: Rhizobiaceae) has comprised of gram negative soil borne bacteria with various life strategies including saprophytism, parasitism (causes crown gall or hairy root diseases) and mutualism (induces root nodules on legume plants) (Zahradnik et al., 2018). Since it was first proposed by Conn, (1942) many changes have been taken place in Agrobacterium systematics both in generic and species levels. Till the end of $20^{\text {th }}$ century, Agrobacterium strains were classified within species $A$. radiobacter, $A$. tumefaciens, A. rhizogenes, A.rubi and A. vitis. In the last twenty years, as the result of investigations of new strains obtained from different hosts and locations many other species and genomic species (e.g. A. larrymoorei, A. albertimagni, A. arsenijevicii, A. deltaense, $A$. salinitolerans, $A$. rosae and A. bohemicum) have been added to the genus (Bouzar et al., 1995; Salmassi et al., 2002; Kuzmanovic et al., 2015a; Yan et al., 2017a; Yan et al., 2017b; Kuzmanovic et al., 2018; Zahradnik et al., 2018). Additionally according to new molecular phylogenetic findings, some species were transferred to the genus Agrobacterium from other genera within the Rhizobiaceae family (A. pusense, A. nepotum and A. skierniewicense), likewise transfers from Agrobacterium to the other genera (Rhizobium rhizogenes and Allorhizobium vitis) were also occurred (Panday et al., 2011; Pulawska et al., 2012a; Pulawska et al., 2012b; Mousavi et al., 2015). Currently, there are 14 binomial species within the genus Agrobacterium in addition to several genomic species (Genomovars) which are not formally named yet (FloresFelix et al., 2020).

Chickpeas (Cicer arietinum L.), the host plant investigated in the study, is the second most cultivated pulse crop in the World and it is in the first rank in Turkey (FAOSTAT 2016; Gülümser, 2016). Although some strains of Agrobacterium causes crown gall or hairy root diseases on many host plants, there have been no records for the Chickpeas so far. One Agrobacterium species, A. pusense, isolated and identified from rhizosphere of chickpea but there is no data for its pathogenicity capability on the host (Panday et al., 2011). Contrarily, some strains of the genus Agrobacterium have been reported as root-nodulating symbionts of chickpeas from several countries like Tunisia and Iran (Saidi et al., 2011; Rouhrazi \& Khodakaramian, 2015). Additionally, some root endophytic Agrobacterium isolates, which are not able to produce root nodules when reinoculated to the original host, were reported from root nodules of $C$. arietinum L. (Romdhane et al., 2009). Despite their ecological and economical importance, there are few studies on Agrobacterium in Turkey when compared to the World. Most of these studies are about some in-vivo applications to determine the susceptibilities of various crops including chickpeas, against pathogenic Agrobacterium strains (mostly foreign strains). Additionally, studies on biotechnological applications like Agrobacterium-mediated transformation of economically important plants, including chickpeas, are also common (Karakaya \& Özcan, 2000; Akbulut et al., 2008). On the other hand, there are only a couple of studies on the species diversity of Agrobacterium and the diseases they caused, in Turkey. Argun et al., (2002) characterized some Agrobacterium vitis (currently Allorhizobium vitis) samples collected from grape cultivars in the Central Anatolia region of Turkey using some PCR based molecular techniques (ITS RFLP) besides biochemical features. Aysan \& Sahin, (2003) reported a crown gall diseases to outbreak caused by $A$. tumefaciens on rose, from the Mediterranian part of Turkey. But species identifications in this study have solely depending on morphology and that is why they are doubtful. In the same year, another A. tumefaciens mediated crown gall disease was reported from the same part of Turkey but from apricot. Again bacterial identifications were carried out according to the morphological and biochemical features (Aysan et al., 2003). Recently some 16S rDNA sequences belonging to A. nepotum which isolated from root nodules of C. arietinum L. in Turkey were submitted to GenBank, but there is no publication available concerning these sequences. Thus, there is a great information gap about the diversity of Agrobacterium species in Turkey.

The goal of this study is to characterize some Agrobacterium isolates obtained from root nodules of $C$. arietinum L. collected from five cities of the Central Anatolia region of Turkey with current molecular techniques.

\section{MATERIAL AND METHOD}

In this study, Cicer arietinum L. plants were collected from five different cities of Central Anatolia region of Turkey during May-August of 2015-2018 (Table 1). Isolations of the bacteria from root nodules were performed according to the method of Vincent, (1970). Standard YMA (Yeast Extract Mannitol Agar) medium was used both for isolations and purifications (by consecutive inoculation), of the bacteria (Vincent, 1970). The purity of the isolates was checked by colony morphology and microscopic examinations using gram staining. Nodulation tests were performed using the method of Vincent, (1970), to determine the nodulation capability of the isolates on their original host (C. arietinum L.). Tests were performed in a growth chamber at $14 \mathrm{~h}$ light and $10 \mathrm{~h}$ dark and with three replicates for each isolate. Nodulation ability of the isolates were evaluated after 5 weeks of incubation. Pathogenicity tests, to visualize 
gall and hairy-root formation, were performed according to the method of Karakaya \& Özcan, (2000). Tests were performed with three replicates for each isolate with the following modification; a growth chamber at 14h light and $10 \mathrm{~h}$ dark was used for the tests, YMB medium was used for growing the bacterial isolates as inoculum.

Table 1. Source information, TP-RAPD profiles and GenBank accession numbers of Agrobacterium isolates obtained in this study.

\begin{tabular}{|c|c|c|c|c|}
\hline \multirow{2}{*}{ Isolate } & \multirow{2}{*}{ Locality } & \multirow{2}{*}{$\begin{array}{c}\text { TP-RAPD } \\
\text { Profile }\end{array}$} & \multicolumn{2}{|c|}{ GenBank Accession Numbers } \\
\hline & & & $16 \mathrm{~S} r D N A$ & recA \\
\hline$\overline{\mathrm{Agr}-\mathrm{Ca}-1}$ & Ankara/Kızılcahamam & $\mathrm{A}$ & MT912699 & MT919277 \\
\hline Agr-Ca-2 & Ankara/Haymana & A & - & - \\
\hline Agr-Ca-3 & Konya/Kulu & A & - & - \\
\hline Agr-Ca-4 & Konya/Beyşehir & A & - & - \\
\hline Agr-Ca-5 & Sivas/Yıldızeli & B & MT912700 & MT919278 \\
\hline Agr-Ca-6 & Sivas/Ulaş & B & - & - \\
\hline Agr-Ca-7 & Ankara/Nallhhan & B & - & - \\
\hline Agr-Ca-8 & Kurșehir/Merkez & B & - & - \\
\hline Agr-Ca-9 9 & Kırşehir/Çiçekdağ 1 & B & - & - \\
\hline Agr-Ca-10 & Konya/Ereğli & B & - & - \\
\hline Agr-Ca-11 & Kayseri/Kocasinan & $\mathrm{C}$ & MT912701 & MT919279 \\
\hline Agr-Ca-12 & Kayseri/Yahyalı & $\mathrm{C}$ & - & - \\
\hline
\end{tabular}

Fresh bacterial cultures for the genomic DNA extractions were prepared using TY (Tryptone Yeast Extract) broth media (Ditta et al., 1987) with the conditions explained in Gurkanli et al., (2013). Genomic DNA extractions from broth cultures were conducted using $\mathrm{CTAB} / \mathrm{NaCl}$ miniprep method and extracted DNA was stored in $-20^{\circ} \mathrm{C}$ prior to use (Temizkan \& Arda, 2004). A TPRAPD (Two primers random amplified polymorphic DNA) analysis was performed for discriminating between the distinct species (or genotypes) within our isolate collection. The analysis was performed using the primer set $879 \mathrm{~F} /$ 1522R (Rivas et al., 2001) with conditions given in Table 2. PCR amplifications were performed using a Techne TCPLUS (Bibby Scientific, Stone, UK) thermal cycler. Presence of virulence (virA, protein kinase) and nodulation (nodD, autoregulatory) genes were investigated in the bacteria to determine the symbiosis type (mutualism or parasitism) between the bacteria and the host plant, $C$. arietinum L. Primer sets, VirA1F/virA2R (Velazquez et al., 2005) and Y5/Y6 (Zeze et al., 2001) were used for PCR amplifications of virA and nodD, respectively. The conditions used for PCR amplifications are given in Table 2. Consequently, one representative isolate from each TPRAPD pattern observed was chosen for the further molecular analyses. The symbiosis types and geographical sources of the isolates were also considered as a criterion during the selection process. Characterizations of the representative isolates were conducted with phylogenetic analyses depending on nucleotide sequences of, 16S rDNA and a housekeeping gene, recA. Primer sets, fd1 / rd2 (Zhang et al., 1999) and recA-Forward / recA-Reverse (Gaunt et al., 2001) were used for PCR amplifications of $16 \mathrm{~S}$ rDNA and recA genes, respectively. The conditions used for both PCR amplifications are stated in Table 2.

Table 2. Primers and PCR conditions used for amplifications of genes analysed in this study.

\begin{tabular}{|c|c|c|c|c|c|c|c|}
\hline$\overline{\text { Gene }}$ & Primer & ID & $\mathbf{C}$ & $\mathbf{D}$ & $\overline{\mathbf{A}}$ & $\mathbf{E}$ & FE \\
\hline TP-RAPD analysis & 879F/1522R (Rivas et al., 2001) & $95^{\circ} \mathrm{C} / 5 \mathrm{~min}$ & $\times 35$ & $94^{\circ} \mathrm{C} / 1 \mathrm{~min}$ & $45^{\circ} \mathrm{C} 1 \mathrm{~min}$ & $72^{\circ} \mathrm{C} / 2 \mathrm{~min}$ & $72^{\circ} \mathrm{C} / 10 \mathrm{~min}$ \\
\hline $16 \mathrm{~S}$ rDNA & pA/pF (Zhang et al., 1999) & $95^{\circ} \mathrm{C} 3 \mathrm{~min}$ & $\times 35$ & $94^{\circ} \mathrm{C} / 1 \mathrm{~min}$ & $55^{\circ} \mathrm{C} 1 \mathrm{~min}$ & $72^{\circ} \mathrm{C} / 1 \mathrm{~min}$ & $72^{\circ} \mathrm{C} / 5 \mathrm{~min}$ \\
\hline recA & recA-Forward/recA-Reverse (Gaunt et al., 2001) & $95^{\circ} \mathrm{C} 5 \mathrm{~min}$ & $\times 35$ & $95^{\circ} \mathrm{C} / 45 \mathrm{~s}$ & $50^{\circ} \mathrm{C} 1 \mathrm{~min}$ & $72^{\circ} \mathrm{C} / 1 \mathrm{~min}$ & $72^{\circ} \mathrm{C} / 2 \mathrm{~min}$ \\
\hline virA & VirA1F/virA2R (Velazquez et al., 2005) & $95^{\circ} \mathrm{C} 5 \mathrm{~min}$ & $\times 35$ & $94^{\circ} \mathrm{C} / 1 \mathrm{~min}$ & $51^{\circ} \mathrm{C} 1 \mathrm{~min}$ & $72^{\circ} \mathrm{C} / 75 \mathrm{sec}$ & $72^{\circ} \mathrm{C} / 10 \mathrm{~min}$ \\
\hline $\operatorname{nod} D$ & Y5/Y6 (Zeze et al., 2001) & $95^{\circ} \mathrm{C} 5 \mathrm{~min}$ & $\times 35$ & $94^{\circ} \mathrm{C} / 1 \mathrm{~min}$ & $55^{\circ} \mathrm{C} 1 \mathrm{~min}$ & $72^{\circ} \mathrm{C} / 1 \mathrm{~min}$ & $72^{\circ} \mathrm{C} / 10 \mathrm{~min}$ \\
\hline
\end{tabular}

A $50 \mu \mathrm{PCR}$ reaction for all amplifications was prepared with, $25 \mu \mathrm{l}$ of GoTaq ${ }^{\circledR}$ Colorless Master Mix, 2X (Promega Corporation, Madison, WI, USA), genomic DNA $<0.5 \mu \mathrm{g}, \quad 0.4 \mathrm{pmol}$ of each primer (in final concentration) and sterile $\mathrm{ddH}_{2} \mathrm{O}$ (up to $50 \mu \mathrm{l}$ ). PCR products were electrophoresed on $1 \%$ (2.5\% for TPRAPD) agarose gel prepared with $1 \mathrm{X}$ TBE buffer and visualized using a Photo-Print Digital Imaging System (Vilber Lourmat, France).

Nucleotide sequencings for $16 \mathrm{~S}$ rDNA and $\mathrm{rec} A$ genes of the selected isolates were performed commercially by Macrogen Europe (Amsterdam, The Netherlands) with the same primers used for PCR amplifications. Nucleotide sequences obtained from both strands were assembled using BioEdit (Hall, 1999). For phylogenetic analyses, data sets were created for each of 16S rDNA and recA genes using the haplotypes (downloaded from GenBank) given in legends of Figures 2 and -3 , together with our new sequences (Table 1). On the other hand, most Agrobacterium isolates (recA and 16S rDNA sequences) in GenBank are still remaining with the older nomenclature (e.g. Rhizobium nepotum, Rhizobium pusense, Rhizobium skierniewicense etc.) and this situation have causing some confusions, thus should be revised by the original submitters. ClustalX (Thompson et al., 1997) was used for multiple nucleotide sequence alignments. To determine the best fitting substitution models for our data sets, Akaike's information criterion (AIC) and Bayesian information criterion (BIC) tests were performed using the jModelTest v. 0.1 package program (Guindon \& Gascuel, 2003; Posada, 2008). Neighbor-joining (NJ), Maximum parsimony (MP) and Maximum likelihood (ML) algorithms were used to determine the phylogenetic relationships among haplotypes. NJ and MP analyses were performed using software program PAUP* v. 4.0b10 (Swofford, 1998) and PhyML 3.0 (Guindon \& Gascuel, 2003) was used for the ML analyses. MP analyses were performed using a heuristic search approach with the TBR 
swapping algorithm (10 random repetitions). To test the reliability of the nodes on the trees, Bootstrap tests were performed with 10000 replicates for all analyses.

All new sequences obtained in this study were deposited in the NCBI data bank under accession numbers MT912699-MT912701 and MT919277-MT919279 (Table 1).

\section{RESULTS}

As the result of isolations, twelve bacterial isolates were obtained from root nodules of $C$. arietinum L. collected from 5 cities of Central Anatolia part of Turkey (Table 1). Although the isolates were collected from active root nodules of $C$. arietinum $\mathrm{L}$, none of them produced root nodules on the original host in the nodulation tests. Moreover, PCR amplification for nodD gene from these twelve isolates did not reveal any product. Similarly, none of the twelve isolates induced tumour-like structures (galls) on the stems or caused root diseases (hairy-root) on $C$. arietinum $\mathrm{L}$ in pathogenicity tests. Additionally, PCR amplification from these isolates for virulence gene, virA, did not produce any DNA band. Results of TP-RAPD analysis revealed three patterns suggesting three genetically different groups within our isolate collection (Figure 1, Table 1). From each TP-RAPD pattern, also considering the geographical location, following representative isolates were selected for further molecular analyses; from Pattern-A: Agr-Ca-1, Pattern-B: Agr-Ca-5 Pattern-C: Agr-Ca-11.

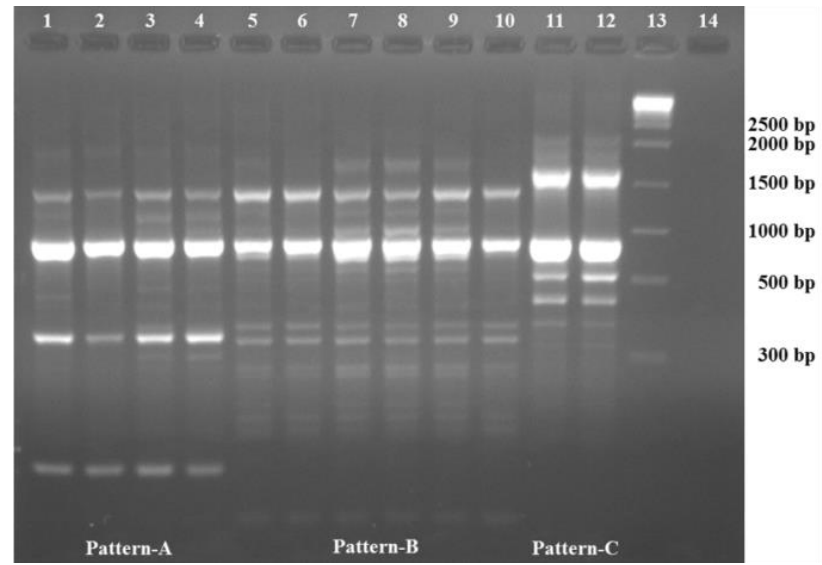

Figure 1. TP-PARD patterns of Agrobacterium isolates obtained in this study. 1) Agr-Ca-1, 2) Agr-Ca-2, 3) Agr-Ca-3, 4) Agr-Ca-4, 5) Agr-Ca5, 6) Agr-Ca-6, 7) Agr-Ca-7, 8) Agr-Ca-8, 9) Agr-Ca-9, 10) Agr-Ca-10, 11) AgrCa-11, 12) Agr-Ca-12, 13) 1 kb DNA Ladder (Norgen), 14) Negative control.

As the result of nucleotide sequencings, the variative thus informative first half of $16 \mathrm{~S}$ rDNA (approx. 900 bp) were obtained from isolates, Agr-Ca-1, Agr-Ca-5 and Agr-Ca-11. Results of BLAST (Basic Local Alignment Search Tool, https://blast.ncbi.nlm.nih.gov/Blast.cgi) search for our new 16S rDNA haplotypes revealed that all isolates obtained in this study are belonging to the genus Agrobacterium. Thus, a data set was created with the $16 \mathrm{~S}$ rDNA haplotypes belonging to type strains of available Agrobacterium species and Genomovars (see legend of Figure 2). Phylogenies were constructed using 850 aligned nucleotides with 76 variable sites. AIC and BIC tests suggested the GTR+I+G (I: 0.785; G: 0.624) and TrN+I+G (I: 0.79; G: 0.655) substitution models, respectively. Because of their higher bootstrap values, NJ (Figure 2) and ML (only the bootstrap values are given in Figure 2) trees created using the GTR $+\mathrm{I}+\mathrm{G}$ model were prefered in the study. MP analysis was depending on 56 synapomorphic sites and yielded 24 equally most parsimonious trees with 117 steps in length (CI: 0.717949, RI: 0.852018, HI: $0.282051)$. Bootstrap values derived from MP analysis also given on Figure 2.

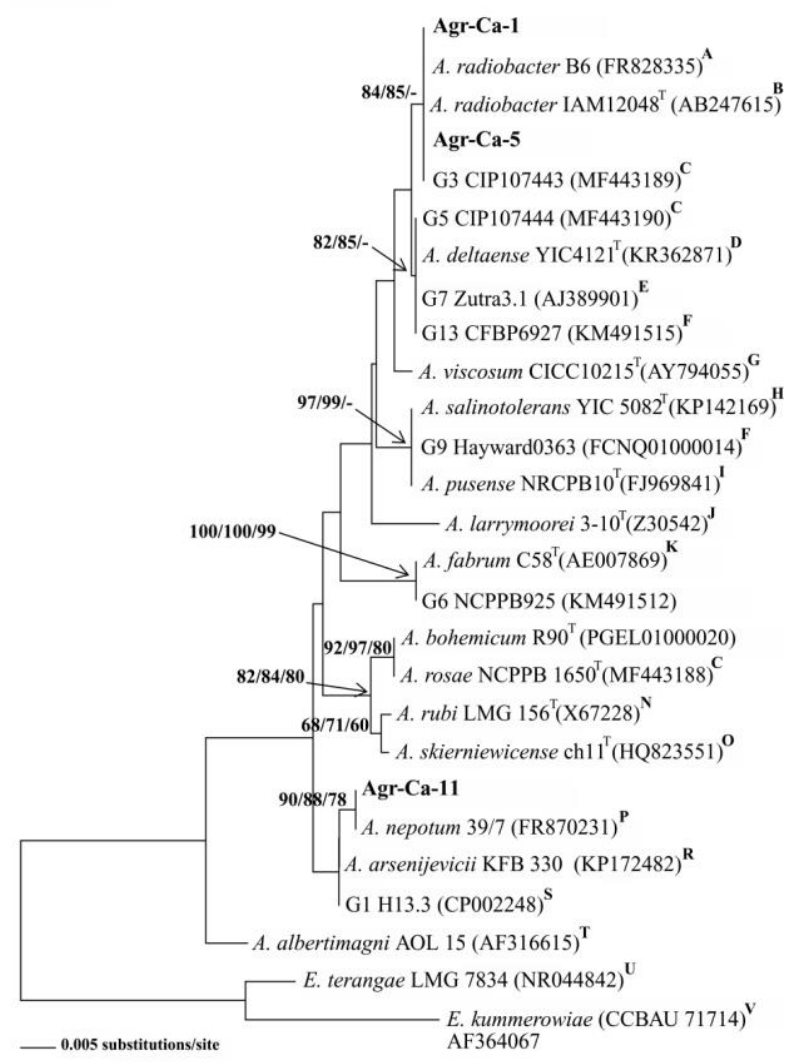

Figure 2. NJ tree derived from nucleotide sequences of $16 \mathrm{~S}$ rDNA haplotypes obtained in this study (Bold) and the ones downloaded from GenBank (given with GenBank accession numbers). The tree has rooted with $r e c A$ haplotypes of $E$. terangae and E. kummerowiae. The bootstrap values $(\geq 50 \%)$ derived from NJ, ML and MP analyses have stated on the tree with the same order.

${ }^{A}$ Lee et al., (Unpublished); ${ }^{B}$ Bautista-Zapanta et al., (2009); ${ }^{C}$ Kuzmanovic et al., (2018); DYan et al., (2017a); E Mougel et al., (Unpublished); F Regsiter \& Williams (Unpublished); ${ }^{\mathrm{G}} \mathrm{Liu}$ et al., (Unpublished); ${ }^{\mathrm{H}}$ Yan et al., (2017b); 'Panday et al., (2011); 'BBouzar et al., (1995) ; ${ }^{\mathrm{K}}$ Goodner et al., (2001); L ${ }^{\mathrm{M}}$ Mousavi et al., (2015); MZahradnik et al., (2018); ${ }^{N}$ Willems \& Collins, (1993); ${ }^{\circ}$ Pulawska et al., (2012a); PPulawska et al., (2012b); ${ }^{\mathrm{R}}$ Kuzmanovic et al., (2015a); ${ }^{\mathrm{S}}$ Wibberg et al., (2011); ${ }^{\mathrm{T}}$ Salmassi et al., (2002); ${ }^{\mathrm{U}}$ De Lajudie et al., 1994; ${ }^{\mathrm{V}}$ Wei et al., 2002. 
Although they showed different TP-RAPD patterns, isolates Agr-Ca-1 (representative of Pattern-A) and Agr-Ca-5 (representative of Pattern-B) showed the same $16 \mathrm{~S}$ rDNA haplotype with each other and also with A. radiobacter isolates, IAM $12848^{\mathrm{T}}$ (Type strain), B6 and Agrobacterium Genomovar 3 isolate CIP107443. This lineage was supported with $84 \%$ and $85 \%$ bootstrap values in NJ and ML trees, respectively. The lineage composed of Agrobacterium Genomovars -5, -7, -13 and A. deltaense isolate $\mathrm{YIC} 4121^{\mathrm{T}}$, which showed the same 16S rDNA haplotype with each other, appeared as sister to the lineage above (Figure 2). The third isolate, Agr-Ca-11, showed the same $16 \mathrm{~S}$ rDNA haplotype with $A$. nepotum type strain $39 / 7^{\mathrm{T}}$. The relationship between these two haplotypes was supported with $90 \%, 88 \%$ and $78 \%$ bootstrap values in the NJ, ML and MP trees, respectively. A. arsenijevicii type strain KFB $330^{\mathrm{T}}$ and Agrobacterium Genomovar 1 isolate H13.3 also appeared in the same lineage with Agr-Ca-11 (Figure 2). In general, relationships within this lineage were supported with significant bootstrap values $(\geq 65)$.

To assign our selected isolates to one of the valid Agrobacterium species (or genomovars), approximately 570 bp of recA gene were obtained and subjected to phylogenetic analyses. The data set used for phylogenetic analyses was containing the recA haplotypes of type strains of available Agrobacterium species. Additionally, recA haplotypes of isolates representing available Agrobacterium Genomovars as well as recA haplotypes some $A$. radiobacter and $A$. nepotum isolates also included to the data set (see legend of Figure 3 ). Analyses were carried out on 373 aligned nucleotides containing 135 variable sites. Both AIC and BIC tests suggested TIM2+I+G (I: 0.513; G: 0.795) substitution model. MP analysis which gave 17 most parsimonious trees (Length: 458 steps, CI: 0.423581, RI: 0.667925, HI: 0.576419) was conducted using 117 synapomorphic characters. NJ tree created using TIM2+I+G model was given in Figure 3 and bootstrap values derived from ML and MP analyses were indicated on the same tree. In the tree, our isolates Agr-Ca1 and Agr-Ca-5 were placed within A. radiobacter lineage which composed of three different haplotypes (Figure 3 ). Agr-Ca-1 showed the same $\operatorname{rec} A$ haplotype with isolate CFBP $5522^{\mathrm{T}}$, the type strain of $A$. radiobacter, and also with isolate CFBP 5621. A. radiobacter isolate B6 appeared as sister and this relationship was supported with $62 \%, 60 \%$ and $60 \%$ bootstrap values in NJ, ML and MP trees, respectively.

Our second A. radibacter isolate, Agr-Ca-5, showed the same recA haplotype with isolates, Kerr 14 and CCNWGS and appeared as sister to the sub-lineage above. Bootstrap values supporting this relationship were $96 \%$, $92 \%$ and $98 \%$ in NJ, ML and MP trees, respectively. Nucleotide sequence similarities among all three $A$. radiobacter recA haplotypes were determined as higher than $98.1 \%$. Concordant with the $16 \mathrm{~S}$ rDNA phylogeny, isolate Agr-Ca-11 appeared as related with A. nepotum lineage in $r e c A$ phylogeny. This relationship has supported with $100 \%$ bootstrap values in all trees created using NJ, ML and MP algoritms (Figure 3). Nucleotide sequence similarity between Agr-Ca-11 and the type strain of $A$. nepotum (isolate $39 / 7^{\mathrm{T}}$ ) was determined as $97.8 \%$

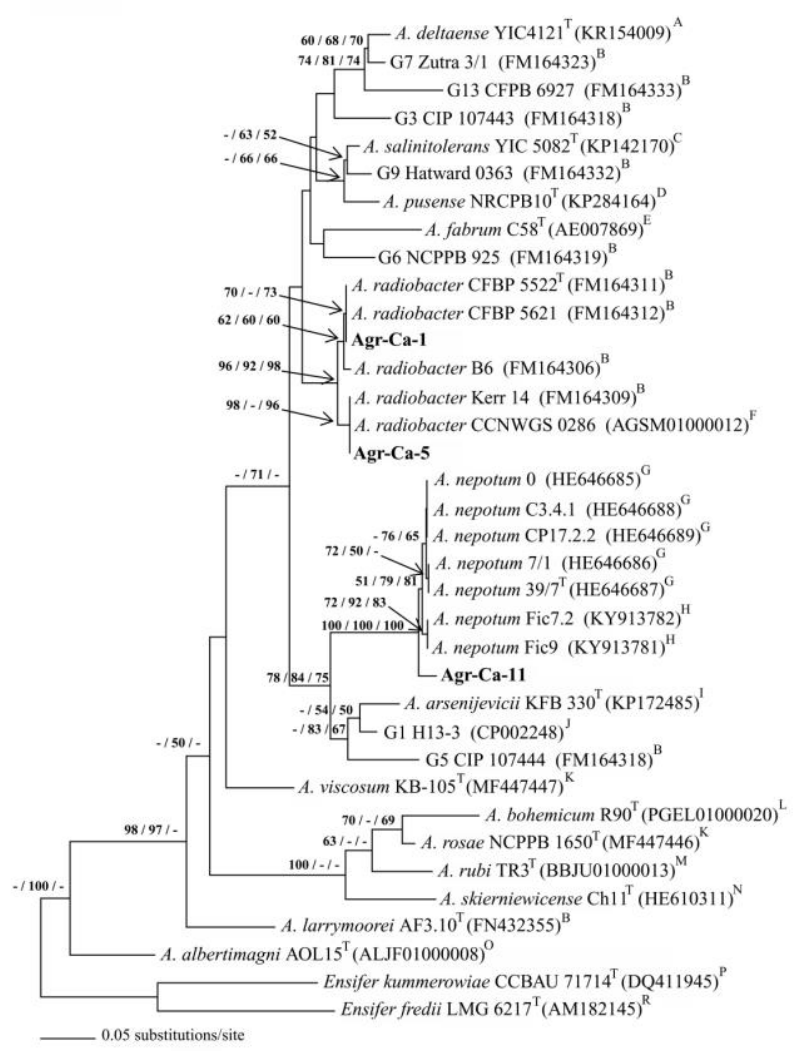

Figure 3. NJ tree derived from nucleotide sequences of $\mathrm{rec} A$ haplotypes obtained in this study (Bold) and the ones downloaded from GenBank (given with GenBank accession numbers). The tree has rooted with recA haplotypes of E. kummerowiae and $E$. fredii. The bootstrap values $(\geq 50 \%)$ derived from ML and MP analyses have also stated on the tree.

${ }^{A}$ Yan et al., (2017a); ${ }^{B}$ Costechareyre et al., (Unpublished); ${ }^{C}$ Yan et al., (2017b); ${ }^{\mathrm{D} K u z m a n o v i c ~ e t ~ a l ., ~(2015 a) ; ~}{ }^{\mathrm{E}}$ Goodner et al., (2001); ${ }^{\mathrm{F}} \mathrm{Hao}$ et al., (2012); ${ }^{\mathrm{C}}$ Pulawska et al., (2012b); ${ }^{H}$ Mafakheri et al., (2019); ' Kuzmanovic et al., (2015b); ${ }^{\text {WWibberg et }}$ al., (2011); ${ }^{\mathrm{K}}$ Kuzmanovic et al., (2018); ' ${ }^{2}$ ahradnik et al., (2018); ${ }^{\mathrm{M}}$ Katano et al., (Unpublished); ${ }^{\mathrm{N} S h a m s ~ e t ~ a l ., ~(2013) ; ~}{ }^{\mathrm{O}}$ Trimble et al., (2012); ${ }^{\mathrm{P}}$ Lloret et al., (2007); ${ }^{\mathrm{R}}$ Martens et al., (2007).

\section{DISCUSSION}

During a survey for rhizobia which nodulates $C$. arietinum L. in the Central Anatolia region of Turkey, a group of ( $n: 12)$ bacteria that morphologically dissimilar (much more mucoid and opaque) to classical rhizobia were obtained from root nodules of $C$. arietinum L. TP-RAPD analysis which is a commonly used pre-grouping method in bacteriological studies (Rivas et al., 2001), revealed three patterns within our collection which indicated three 
genetically distinct groups. Phylogenetic analyses depending on nucleotide sequences of two genetic markers, 16S rDNA and recA, designated representative isolates of first two TP-RAPD patterns, Pattern-A (Agr-Ca-1) and Pattern-B (Agr-Ca-5) as A. radiobacter. Although some A. radiobacter isolates have reported from Turkey so far, they were all clinical strains causing infections in humans (Otağ et al., 2007). Thus according to the available literature, there has been only one soil-borne Agrobacterium species, A. tumefaciens, reported from Turkey (Aysan \& Sahin, 2003; Aysan et al., 2003). On the other hand, identifications of the bacteria in all these studies were depending on some morphological and biochemical features, thus were highly doubtful. That is why, isolates, Agr-Ca-1 and Agr-Ca-5, in this study are the first properly (with current molecular phylogenetic techniques) identified soil-borne $A$. radiobacter isolates from Turkey. Phylogenetic analyses designated isolate Agr-Ca-11, the representative isolate of TP-RAPD Pattern-C, as A. nepotum. This species was first described by Pulowska et al., (2012b) from tumours on several plant species in Europe. Since then, it has been reported from several countries as pathogen or root nodule endophytes (Mafakheri et al., 2019; El Yemlahi, Unpublished). In GenBank, there is one 16S rDNA sequence, submitted from Gaziantep University (Gaziantep-Turkey), belonging to a nodule endophytic $A$. nepotum strain which isolated from root nodules of $C$. arietinum L. in Turkey. On the other hand, there is no available publication on the strain, thus its exact origin and other features are unknown. But together with our finding, it may indicate that $A$. nepotum is one of the common nodule endophytic Agrobacterium species in chickpea fields of Central and Southeastern Anatolia. But this presumption must be confirmed with comprehensive investigations. In authentication and pathogenicity tests, none of the twelve isolates produced root nodules or disease symptoms on chickpeas. Additionally, no appropriate DNA bands were observed as the result of nodD and virA amplifications. These results have proved the absence of the genetic accessories necessary for the nodulation or virulence processes in these isolates therefore they all are nodule-endophytes (nonnodulating). Presence of nodule-endophytic bacteria in root nodules have been reported from various legume species including Melilotus dentatus, $P$. vulgaris $\mathrm{L}$. and $C$. arietinum L. (Mhamdi et al., 2005; Wang et al., 2006; Ben Romdhane et al., 2009). Although the mechanism underlying this biological phenomenon is unknown, Ben Romdhane et al., (2009) suggested that water deficiency conditions induce the colonisation of chickpea nodules by non-symbiotic or non-specific Rhizobium and Agrobacterium isolates. If we consider the geographical and climatic features of Central Anatolia during the nodulation period of chickpea seedlings (approx. during June-July), a water deficiency condition is highly possible. This unfavourable situation possibly may have caused the infiltration of nodule-endophytic Agrobacterium isolates to chickpea root nodules. Although these bacteria are avirulent (gives no direct harm to the plant) it may indirectly reduce the crop productivity by competing with the actual rhizobial partner of $C$. arietinum $\mathrm{L}$. in the rhizosphere. In this context, it has been reported that Agrobacterium isolates may reduce the nodulation of $P$. vulgaris $\mathrm{L}$. by its rhizobial partner, Rhizobium gallicum (Mrabet et al. 2006).

As conclusion, this study presents the first rootendophytic Agrobacterium radiobacter and A. nepotum isolates, which identified using proper molecular phylogenetic techniques, from $C$. arietinum grown in Central Anatolia part of Turkey. Additionally, it gives the first molecular data for A. radiobacter for Turkey.

\section{REFERENCES}

Akbulut, M., Yücel, M. \& Öktem, H.A. (2008). Analysis and optimization of DNA delivery into chickpea (Cicer arietinum L.) seedlings by Agrobacterium tumefacience. African Journal of Biotechnology, 7, 1011-1017.

Argun, N., Momol, M.T., Maden, S., Momol, E.A., Reid, C.L., Çelek, H. \& Burr, T.J. (2002). Characterization of Agrobacterium vitis strains isolated from Turkish grape cultivars in the Central Anatolia Region. Plant Disease, 86, 162166.

Aysan, Y., Sahin, F., Mirik, M., Donmez, M.F. \& Tekman, H. (2003). First report of crown gall of apricot (Prunus armeniaca) caused by Agrobacterium tumefaciens in Turkey. Plant Pathology, 52, 793.

Aysan, Y. \& Sahin, F. (2003). An outbreak of crown gall disease on rose caused by Agrobacterium tumefaciens in Turkey. Plant Pathology, 52, 780.

Bautista-Zapanta, J.N., Arafat, H.H., Tanaka, K., Sawada, H. \& Suzuki, K. (2009). Variation of 16S-23S internally transcribed spacer sequence and intervening sequence in rDNA among the three major Agrobacterium species. Microbiological Research, 164, 604-612.

Ben Romdhane, S., Trabelsi, M., Aouani, M.E., de Lajudie, P. \& Mhamdi, R. (2009). The diversity of rhizobia nodulating chickpea (Cicer arietinum) under water deficiency as a source of more efficient inoculants. Soil Biology and Biochemistry, 41, 2568-2572. 
Bouzar, H., Chilton, W.S., Nesme, X., Dessaux, Y., Vaudequin, V., Petit, A., Jones, J.B. \& Hodge, N.C. (1995). A new Agrobacterium strain isolated from aerial tumors on Ficus benjamina L. Applied and Environmental Microbiology, 61, 65-73.

Conn, H.J. (1942). Validity of the genus Alcaligenes. Journal of Bacteriology, 44, 353-360.

De Lajudie, P., Willems, A., Pot, B., Dewettinck, D., Maestrojuan, G., Neyra, M., Collins, M.D., Dreyfus, B., Kersters, K. \& Gillis, M. (1994). Polyphasic taxomomy of Rhizobia: emendation of the genus Sinorhizobium and description of $S$. meliloti comb nov., S.saheli sp. nov., S. teranga sp. nov. International Journal of Systematic Bacteriology, 44, 715-733.

Ditta, G., Virts, E., Palomares, A. \& Kim, C.H. (1987). The nifA gene of Rhizobium meliloti is oxygen regulated. Journal of Bacteriology, 169, 32173223.

FAOSTAT. (2016). http://faostat.fao.org/faostat/

Flores-Felix, J.D., Menendez, E., Peix, A. \& GraciaFraile, P. (2020). History and current taxonomic status of genus Agrobacterium. Systematic and Applied Microbiology, 43, 126046.

Gaunt, M.W., Turner, S.L., Rigotier-Gois, L., LloydMacgilp, S.A. \& Young, J.P.W. (2001). Phylogenies of atpD and recA support the small subunit rRNA-based classification of Rhizobia. International Journal of Systematic and Evolutionary Microbiology, 51, 2037-2048.

Goodner, B., Hinkle, G., Gattung, S., Miller, N., Blanchard, M., Qurollo, B., Gold-man, B.S., Cao, Y., Askenazi, M., Halling, C., Mullin, L., Houmiel, K., Gordon, J.,Vaudin, M., Iartchouk, O., Epp, A., Liu, F., Wollam, C., Allinger, M., Doughty,D., Scott, C., Lappas, C., Markelz, B., Flanagan, C., Crowell, C., Gurson, J., Lomo,C., Sear, C., Strub, G., Cielo, C. \& Slater, S. (2001). Genome sequence of the plantpathogen and biotechnology agent Agrobacterium tumefaciens C58. Science, 294, 2323-2328.

Guindon, S. \& Gascuel, O. (2003). A simple, fast and accurate algorithm to estimate large phylogenies by maximum-likelihood. Systematic Biology, 52, 696-704

Gurkanli, C.T., Ozkoc, I. \& Gunduz, I. (2013). Genetic diversity of rhizobia nodulating common bean (Phaseolus vulgaris L.) in the Central Black Sea region of Turkey. Annals of Microbiology, 63, 971-987.
Gülümser, A. (2016). Dünyada ve Türkiye'de yemeklik dane baklagillerin durumu. Tarla Bitkileri Merkez Araştırma Enstitüsü Dergisi, 25, 292-298.

Hall, T.A. (1999). BioEdit: a user-friendly biological sequence alignment editor and analysis program for Windows 95/98/NT. Nucleic Acids Symposium Serie, 41, 95-98.

Hao, X., Xie, P., Johnstone, L., Miller, S.J., Rensing, C. \& Wei, G. (2012). Genome sequence and mutational analysis of plant-growth-promoting bacterium Agrobacterium tumefaciens CCNWGS0286 isolated from a zinc-lead mine tailing. Applied and Environmental Microbiology, 78, 5384-5394.

Karakaya, A. \& Özcan, S. (2000). Susceptibility of chickpea (Cicer arietinum L.) cultivars to Agrobacterium tumefaciens (Smith and Townsend) Conn. Turkish Journal Biology, 24, 285-289.

Kuzmanovic, N., Pulawska, J., Prokic, A., Ivanovic, M., Zlatković, N., Jones, J.B. \& Obradovic, A. (2015a). Agrobacterium arsenijevicii sp. nov., isolated from crown gall tumors on raspberry and cherry plum. Systematic and Applied Microbiology, 38, 373-378.

Kuzmanovic, N., Prokic, A., Ivanovic, M., Zlatkovic, N., Gasic, K. \& Obradovic, A. (2015b). Genetic diversity of tumorigenic bacteria associated with crown gall disease of raspberry in Serbia. European Journal of Plant Pathology, 142, 701713.

Kuzmanovic, N., Puławska, J., Smalla, K. \& Nesme, X. (2018). Agrobacterium rosae sp. nov., isolated from galls on different agricultural crops. Systematic and Applied Microbiology, 41, 191197.

Lloret, L., Ormeno-Orrillo, E., Rincon, R., MartinezRomero, J., Rogel-Hernandez, M.A. \& Martinez-Romero, E. (2007). Ensifer mexicanus sp. nov. a new species nodulating Acacia angustissima (Mill.) Kuntze in Mexico. Systematic and Applied Microbiology, 30, 280290.

Mafakheri, H., Taghavi, S.M., Pulowska, J., de Lajudie P., Lassalle, F. \& Osdaghi, E. (2019). Two novel genomospecies in the Agrobacterium tumefaciens species complex associated with rose crrown gall. Phytopathology, 109, 1859-1868.

Martens, M., Delaere, M., Coopman, R., De Vos, P., Gillis, M. \& Willems, A. (2007). Multilocus sequence analysis of Ensifer and related taxa. International Journal of Systematic and Evolutionary Microbiology, 57, 489-503. 
Mhamdi, R., Mrabet, M., Laguerre, G., Tiwari, R. \& Aouani, M.E. (2005). Colonization of Phaseolus vulgaris nodules by Agrobacterium-like strains. Canadian Journal of Microbiology, 51, 105-111.

Mousavi, S.A., Willems, A., Nesme, X., de Lajudie, P. \& Lindström, K. (2015). Revised phylogeny of Rhizobiaceae: proposal of the delineation of Pararhizobium gen. nov., and 13 new species combinations, Systematic and Applied Microbiology, 38, 84-90.

Mrabet, M., Mnasri, B., Romdhane, S.B., Laguerre, G., Aouani, M.E. \& Mhamdi, R. (2006). Agrobacterium strains isolated from root nodules of common bean specifically reduce nodulation by Rhizobium gallicum. FEMS Microbiology Ecology, 56, 304-309.

Otağ, F., Tezcan, S., Özturhan, H., Aslan, G., Kuyucu, N. \& Emekdaş, G. (2007). Emerging nonfermenter Gram negative pathogens in paediatric patients: Rhizobium radiobacter bacteremia. Journal of Pediatric Infection, 1, 143-146.

Panday, D., Schumann, P. \& Das, S.K. (2011). Rhizobium pusense sp. nov., isolated from the rhizosphere of chickpea (Cicer arietinum L.). International Journal of Systematic and Evolutionary Microbiology, 61, 2632-2639.

Pulawska, J., Willems, A. \& Sobiczewski, P. (2012). Rhizobium skierniewicense sp. nov., isolated from tumours on chrysanthemum and cherry plum. International Journal of Systematic and Evolutionary Microbiology, 62, 895-899.

Pulawska, J., Willems, A., De Meyer, S.E. \& Sule, S. (2012). Rhizobium nepotum sp. nov. isolated from tumors on different plant species. Systematic and Applied Microbiology, 35, 215-220

Posada, D. (2008). jModel test: phylogenetic model averaging. Molecular Biology and Evolution, 25, 1253-1256.

Rivas, R., Velázquez, E., Valverde, A., Mateos, P.F. \& Martínez-Molina, E. (2001). A two primers random amplified polymorphic DNA procedure to obtain polymerase chain reaction fingerprints of bacterial species. Electrophoresis, 22, 10861089.

Romdhane, S.B., Trabelsi, M., Aouani, M.E., de Lajudie, P. \& Mhamdi, R. (2009). The diversity of rhizobia nodulating chickpea (Cicer arietinum) under water deficiency as a source of more efficient inoculants. Soil Biology and Biochemistry, 41, 2568-2572.

Rouhrazi, K. \& Khodakaramian, G. (2015). Phenotypic and genotypic diversity of root-nodulating bacteria isolated from chickpea (Cicer arietinum
L.) in Iran. Annals of Microbiology, 65, 22192227.

Saidi, S., Mnasri, B. \& Mhamdi, R. (2011). Diversity of nodule-endophytic agrobacteria-like strains associated with different grain legumes in Tunisia. Systematic and Applied Microbiology, 34, 524-530.

Salmassi, T.M., Venkateswaren, K., Satomi, M., Nealson, K.H., Newman, D.K. \& Hering, J. (2002). Oxidation of arsenite by Agrobacterium albertimagni, AOL15, sp. nov., isolated from Hot Creek, California. Geomicrobiology journal, 19, 53-66.

Shams, M., Vial, L., Chapulliot, D., Nesme, X. \& Lavire, C. (2013). Rapid and accurate species and genomic species identification and exhaustive population diversity assessment of Agrobacterium spp. using recA-based PCR. Systematic and applied microbiology, 36, 351358.

Swofford, D.L. (1998). PAUP* Phylogenetic Analysis Using Parsimony (*and Other Methods). Version 4 beta 10. Sinauer Associates, Sunderland, Massachusetts.

Temizkan, G. \& Arda, N. (2004). Moleküler Biyolojide Kullanılan Yöntemler, 2nd ed. Nobel Tip Kitabevleri, İstanbul.

Thompson, J.D., Gibson, T.J., Plewniak, F., Jeanmougin, F. \& Higgins, D.G. (1997). The ClustalX-Windows interface: Flexible strategies for multiple sequence alignment aided by quality analysis tools. Nucleic Acids Research, 25, 48764882.

Trimble, W.L., Phung le, T., Meyer, F., Gilbert, J.A. \& Silver, S. (2012). Draft genome sequence of Agrobacterium albertimagni strain AOL15. Journal of Bacteriology, 194, 6986-6987.

Velázquez, E., Peix, A., Zurdo-Piñeiro, J.L., Palomo, J.L., Mateos, P.F., Rivas, R., MuñozAdelantado, E., Toro, N., García-Benavides, P. \& Martínez-Molina, E. (2005). The coexistence of symbiosis and pathogenicity-determining genes in Rhizobium rhizogenes strains enables them to induce nodules and tumors or hairy Roots in Plants. Molecular Plant Microbe Interactions, 18, 1325-1332.

Vincent, J.M. (1970). A manuel for the Practical Study of the Root-Nodule Bacteria. Blackwell Scientific Publications, Oxford and Edinburgh, 164p.

Wang, L.L., Wang, E.T., Liu, J., Li, Y. \& Chen, W.X. (2006). Endophytic occupation of root nodules and roots of Melilotus dentatus by Agrobacterium tumefaciens. Microbiology Ecology, 52, 436-443. 
Wei, G.H., Wang, E.T., Tan, Z.Y., Zhu, M.E. \& Chen, W.X. (2002). Rhizobium indigoferae sp. nov. and Sinorhizobium kummerowiae sp. nov., respectively isolated from Indigofera spp. and Kummerowia stipulacea. International Journal of Systematic and Evolutionary Microbiology, 52, 2231-2239.

Wibberg, D., Blom, J., Jaenicke, S., Kollin, F., Rupp, O., Scharf, B., Schneiker-Bekel, S., Sczcepanowski, R., Goesmann, A., Setubal, J.C., Schmitt, R., Puhler, A. \& Schluter, A. (2011). Complete genome sequencing of Agrobacterium sp. H13-3, the former Rhizobium lupini H13-3, reveals a tripartite genome consisting of a circular and a linear chromosome and an accessory plasmid but lacking a tumorinducing Ti-plasmid. Journal of Biotechnology, 155, 50-62.

Willems, A. \& Collins, M.D. (1993). Phylogenetic analysis of rhizobia and agrobacteria based on 16S rRNA gene sequences. International Journal of Systematic Bacteriology, 43, 305-313.

Yan, J., Li, Y., Han, X., Chen, W.F., Zou, W., Xie, Z. \& Li, M., (2017a). Agrobacterium deltaense sp. nov., an endophytic bacteria isolated from nodule of Sesbania cannabina. Archives of Microbiology, 199, 1003-1009.

Yan, J., Li, Y., Yan, H., Chen, W.F., Zhang, X., Wang, E.T., Han, X.Z. \& Xie, Z.H. (2017b). Agrobacterium salinitolerans sp. nov., a salinealkaline-tolerant bacterium isolated from root nodule of Sesbania cannabina. International Journal of Systematic and Evolutionary Microbiology, 67, 1906-1911.

Zahradnik, J., Nunvar, J., Pařízková, H., Kolářová, L., Palyzová, A., Marešová, H., Grulich, M., Kyslíková, E. \& Kyslík, P. (2018). Agrobacterium bohemicum sp. nov. isolated from poppy seed wastes in Central Bohemia. Systematic and Applied Microbiology, 41, 184190.

Zeze, A., Mutch, L.A. \& Young, J.P.W. (2001). Direct amplification of nodD from community DNA reveals the genetic diversity of Rhizobium leguminosarum in soil. Environmental Microbiology, 3, 363-370.

Zhang, X.X., Guo, X.W., Terefework, Z., Paulin, L., Cao, Y.Z., Hu, F.R. \& Lindstrom, K., Li, F.D. (1999). Genetic diversity among rhizobial isolates from field-grown Astragalus sinicus of Southern China. Systematic and Applied Microbiology, 22, 312-320. 